\title{
ANALISIS PERAN FAKTOR PENYEBAB KEMATIAN MATERNAL YANG DAPAT DICEGAH TERHADAP KETERLAMBATAN RUJUKAN DAN PENANGANAN DI KABUPATEN KARAWANG PROVINSI JAWA BARAT
}

\author{
Jasmiati, Firman F.Wirakusumah, Hadyana Sukandar, Farid Husin, \\ Yudi Mulyana Hidayat, Unggul Yudatmo \\ Program Studi D3 Kebidanan, Akbid Pemkab Aceh Utara \\ E-mail : jasmiatif@yahoo.com \\ Departemen Ilmu Obstetri dan Ginekologi Fakultas Kedokteran, Universitas Padjadjaran \\ Departemen Ilmu Epidemiologi dan Biostatistik Fakultas Kedokteran, Universitas Padjadjaran \\ Departemen Ilmu Obstetri Ginekologi, RSUD Kabupaten Karawang
}

\begin{abstract}
Maternal mortality rate is an important indicator of public health quality. Most of the causes of maternal mortality are preventable factors such as patients, health workers, health facilities and referral. The purpose of this study was to analyze of the role of factors maternal mortality could have been prevented to delays in referral and treatment. This is a sequential explanatory mixed method research. The first stage is carried out through quantitative cross sectional study with data capture as much as 65 maternal mortality could have been prevented retrieved from 2015's Maternal Perinatal Audit (AMP) documents in Karawang Regency. The second stage is through qualitative approach with Focused Group Discussion (FGD) and in-depth interviews. The results of quantitative research shows that the majority ( 52 cases or $80,0 \%$ ) of maternal mortality could have been prevented with delays in referral and treatment and there is a significant role of patient factors, health workers, health facilities with delays in referral and treatment while the referral factor does not have a significant role. Qualitative research results indicate that maternal mortality is caused by patient factors such as mother's attitude toward risk, delayed and/or refusing treatment; factors of health workers due to lack of early detection, poor quality of service, lack of skilled professionals and late treatment; health facilities factors due to poor facility; referral factors such as referral refusal, referral inaccuracies and referral delays due to patient's financial factor and team coordination and cross-sectoral cooperation is also contributing factors. The failure of early detection and decision-making due to lack of capacity of health personnel to recognize and capture high-risk cases and failure to effectively provide information, education and communication (KIE) are factors that cause delays in referral and treatment. Therefore, active participation of society, stakeholders, health professionals and policy makers are required to improve the quality of obstetric care to reduce maternal mortality.
\end{abstract}

Keywords : Maternal Mortality, Delays in Referral and Treatment

\begin{abstract}
Abstrak
Kematian maternal menjadi indikator penting derajat kesehatan masyarakat. Sebagian besar penyebab kematian maternal dapat dicegah meliputi faktor pasien, tenaga kesehatan, fasilitas kesehatan dan rujukan. Tujuan penelitian ini adalah menganalisis peran faktor penyebab kematian maternal yang dapat dicegah terhadap keterlambatan rujukan dan penanganan. Desain penelitian menggunakan sequensial eksplanatory mixed method. Tahap pertama secara kuantitatif yaitu cross sectional dengan pengambilan data dari dokumen Audit Maternal Perinatal (AMP) tahun 2015 sebanyak 65 kematian maternal yang dapat dicegah di Kabupaten Karawang. Tahap kedua secara kualitatif melalui Focus Group Discussion (FGD) dan wawancara mendalam. Hasil penelitian kuantitatif menunjukkan sebagian besar kematian maternal yang dapat dicegah mengalami keterlambatan rujukan dan penanganan yaitu 52 kasus $(80,0 \%)$ dan terdapat peran yang bermakna dari faktor pasien, tenaga kesehatan, fasilitas kesehatan terhadap keterlambatan rujukan dan
\end{abstract}


penanganan sedangkan faktor rujukan tidak terdapat peran yang bermakna. Hasil penelitian kualitatif didapatkan penyebab dari faktor pasien karena karakteristik ibu berisiko, terlambat mencari penanganan dan menolak pengobatan, dari faktor tenaga kesehatan karena kurangnya deteksi dini dan kualitas pelayanan, kurangnya tenaga profesional dan terlambat penanganan, dari faktor fasilitas kesehatan karena kurang fasilitas, dari faktor rujukan karena menolak rujukan, kurang tepatnya rujukan dan keterlambatan rujukan terkait biaya dan koordinasi tim serta kerja sama lintas sektor juga merupakan faktor yang berperan. Keterlambatan deteksi dini dan pengambilan keputusan karena kurangnya kemampuan tenaga kesehatan mengenali dan menjaring kasus risiko tinggi serta tidak efektif memberikan komunikasi informasi dan edukasi (KIE) yang menyebabkan keterlambatan rujukan dan penanganan. Diperlukan peran serta masyarakat, stakeholder, tenaga kesehatan dan pengambil kebijakan dalam meningkatkan kualitas pelayanan kebidanan untuk menurunkan kematian maternal.

Kata kunci: Kematian Maternal, Keterlambatan Rujukan dan Penanganan

\section{PENDAHULUAN}

Sasaran pembangunan kesehatan yang akan dicapai tahun 2025 adalah meningkatnya derajat kesehatan masyarakat yang salah satunya ditunjukkan dengan menurunnya AKI. Sasaran Rencana Pembangunan Jangka Menengah Nasional (RPJMN) tahun 2015-2019 yaitu target AKI tahun 2019 adalah 306/100.000 Kelahiran Hidup (KH) (Kemenkes RI, 2015). Target Sustainable Development Goals (SDGs) dengan target tahun 2030 mengurangi rasio kematian maternal global kurang dari 70/100.000 KH (WHO, 2014).

Kasus kematian maternal tertinggi di Indonesia tahun 2012 yaitu Provinsi Jawa Barat sebanyak 804 kasus dari 931.906 jumlah kelahiran hidup dengan AKI 86,3/100.000 KH, sedangkan tahun 2015 mengalami peningkatan yaitu 823 kasus dari 950.541 jumlah kelahiran hidup dengan AKI 86,6/100.000 KH (Dinkes Provinsi Jawa Barat, 2014). Kabupaten Karawang tahun 2014 menduduki urutan kedua tertinggi jumlah kasus kematian maternal di Provinsi Jawa Barat yaitu 59 kasus dari 57.044 jumlah kelahiran hidup dan tahun 2015 mengalami peningkatan sebanyak 68 kasus dari 54.828 jumlah kelahiran hidup (Dinkes Kabupaten Karawang, 2014).

Sebagian besar kematian maternal di negara berkembang dapat dicegah yaitu 37-90\% (Liang dkk, 2011). Sejalan dengan strategi Making Pregnancy Saver (MPS) di Indonesia, maka kematian maternal dapat dicegah lebih dari 70\% (Kemenkes RI, 2014). Penyebab kematian maternal dapat dicegah meliputi faktor pasien, tenaga kesehatan, fasilitas kesehatan dan rujukan (Merali, dkk, 2014). Jumlah kematian maternal yang seharusnya dapat dicegah masih tinggi meskipun berbagai program telah dilaksanakan pemerintah yaitu deteksi dini faktor risiko, pelayanan kesehatan reproduksi remaja, asuhan antenatal, intranatal dan postnatal yang berkualitas dan pemberdayaan perempuan dalam pengambilan keputusan (Kemenkes RI, 2010). Untuk ini dilakukan analisis peran faktor penyebab kematian maternal yang dapat dicegah terhadap keterlambatan rujukan dan penanganan di Kabupaten Karawang.

\section{METODE PENELITIAN}

Rancangan penelitian menggunakan Sequential Explanatory Mixed Method. Tahap pertama penelitian dilakukan dengan metode kuantitatif yaitu cross sectional dan tahap kedua dengan metode kualitatif untuk memperkuat hasil penelitian kuantitatif. Metode kuantitatif untuk mendapatkan peran faktor penyebab kematian maternal yang dapat dicegah terhadap keterlambatan rujukan dan penanganan, data didapatkan dari rekapitulasi kematian maternal dan dokumen Audit Maternal Perinatal (AMP) di Dinas Kesehatan Kabupaten Karawang. Metode kualitatif melalui Focus Group Discussion kepada tenaga kesehatan dan In depth interview kepada keluarga dari ibu yang meninggal periode 1 Januari-31 Desember 2015, tenaga kesehatan 
yang terkait langsung /diwilayah binaannya ada kematian maternal. Penelitian dilakukan di Kabupaten Karawang dari tanggal 26 Oktober 26 November 2016.

\section{HASIL PENELITIAN}

Pengambilan data kuantitatif dan kualitatif didapatkan hasil penelitian sebagai berikut:

\section{1) Karakteristik Ibu}

Tabel 1. Distribusi Frekuensi Karakteristik Ibu Pada Kematian Maternal di Kabupaten Karawang Tahun $2015(n=68)$

\begin{tabular}{clcc}
\hline No & Karakteristik ibu & Jumlah & \% \\
\hline 1 & Umur & & \\
& $<20$ atau> 35tahun & 15 & 22,1 \\
& 20-35 tahun & 53 & 77,9 \\
& & & \\
\hline 2 & Pendidikan & & \\
& Dasar & 56 & 82,4 \\
& Menengah & 11 & 16,2 \\
& Tinggi & 1 & 1,5 \\
\hline 3 & Paritas & & \\
& $\leq 1$ atau $>4$ & 23 & 33,8 \\
& 2-4 & 45 & 66,2 \\
\hline 4 & Jarak Kelahiran & & \\
& $<2$ tahun & 5 & 7,4 \\
& $\geq 2$ tahun & 52 & 76,5 \\
\hline 5 & Kunjungan ANC & & \\
& $<4$ Kali & 18 & 26,5 \\
& $\geq 4$ Kali & 50 & 73,5 \\
\hline 6 & Penyakit Penyerta & & \\
& Ada & 29 & 42,6 \\
& Tidak ada & 39 & 57,4 \\
\hline
\end{tabular}

Tabel 1 menunjukkan bahwa sebagian besar kematian maternal terjadi pada umur 2035 tahun sebanyak 53 kasus (77,9\%), pendidikan dasar sebanyak 56 kasus $(82,4 \%)$, paritas 2-4 sebanyak 45 kasus $(66,2 \%)$, jarak kelahiran $\geq 2$ tahun sebanyak 52 kasus (76,5\%), kunjungan $\mathrm{ANC} \geq 4$ kali sebanyak 50 kasus $(73,5 \%)$ dan ibu tanpa penyakit penyerta sebanyak 39 kasus $(57,4 \%)$.

\section{2) Karakteristik Kematian Maternal}

Tabel 2. Distribusi Frekuensi Karakteristik Kematian Maternal di Kabupaten Karawang Tahun $2015(\mathrm{n}=68)$

\begin{tabular}{clcc}
\hline No & \multicolumn{1}{c}{ Karakteristik } & Jumlah & \% \\
\hline 1 & Penyebab kematian & & \\
& Preeklampsi/eklampsi & 30 & 44,1 \\
& Perdarahan & 17 & 25,0 \\
& Penyakit jantung & 14 & 20,6 \\
& Infeksi & 6 & 8,8 \\
& Emboli & 1 & 1,5 \\
\hline 2 & Periode Kematian & & \\
& Hamil & 16 & 23,5 \\
& Bersalin & 14 & 20,6 \\
& Nifas & 38 & 55,9 \\
\hline 3 & Tempat kematian & & \\
& Non fasilitas kesehatan & 3 & 4,4 \\
& Fasilitas kesehatan & 65 & 95,6 \\
\hline 4 & Rujukan & & \\
& Tidak dirujuk & 7 & 10,3 \\
& Dirujuk & 61 & 89,7 \\
\hline
\end{tabular}

Tabel 2 menunjukkan bahwa sebagian besar kematian maternal dengan penyebab langsung pre eklamsi/eklamsi sebanyak 30 kasus $(44,1 \%)$, terjadi pada masa nifas sebanyak 38 kasus (55,9\%), tempat kematian di fasilitas kesehatan sebanyak 65 kasus (95,6\%), dan hampir semua terjadi pada ibu yang dirujuk sebanyak 61 kasus $(89,7 \%)$.

Tabel 3. Distribusi Frekuensi Kematian Maternal di Kabupaten Karawang Tahun 2015 $(n=68)$

\begin{tabular}{ccc}
\hline Kematian Maternal & Jumlah & \% \\
\hline Dapat dicegah & 65 & 95,6 \\
Tidak dapat dicegah & 3 & 4,4 \\
\hline Total & 68 & 100 \\
\hline
\end{tabular}

Tabel 3 menunjukkan bahwa sebagian besar kematian maternal dapat dicegah sebanyak 65 kasus (95,6\%). Didukung pernyataan partisipan berikut:

"Di community tidak ada kematian tidak bisa dicegah, yang perlu ditingkatkan fungsi bidan desa, yang tidak pernah ANC didatangi, oedema paru dicegah di primer atau di rumah sakit berkaitan time respon, PEB dengan rujukan dini berencana, perdarahan stabilisasi dulu, kelainan jantung harusnya sudah tahu hemodilusi pada kehamilan 28 minggu menyebabkan kegagalan jantung, solusio plasenta ada hipertensi bisa dicegah dari hipertensi. Di rumah sakit yang tidak dapat 
dicegah kematian yang datang terlambat."(RN2 Indepth)

Tabel 4. Distribusi Frekuensi Keterlambatan Rujukan dan Penanganan di Kabupaten Karawang Tahun $2015(\mathrm{n}=65)$

\begin{tabular}{ccc}
\hline $\begin{array}{c}\text { Keterlambatan } \\
\text { Rujukan dan } \\
\text { Penanganan }\end{array}$ & Jumlah & $\%$ \\
\hline Terlambat & 52 & 80,0 \\
Tidak Terlambat & 13 & 20,0 \\
\hline Total & 65 & 100 \\
\hline
\end{tabular}

Tabel 4 menunjukkan bahwa sebagian besar kematian maternal yang dapat dicegah mengalami keterlambatan rujukan dan penanganan yaitu sebanyak 52 kasus $(80,0 \%)$. Seperti penuturan partisipan berikut:

"Kalau dari data kematian yang pernah diaudit, keterlambatan itu ada dimasyarakat yaitu T1, sudah dikonfirmasi ke rumah sakit, sekitar 40-45\% kematian terjadi dalam 24 jam pertama tiba di RS artinya kan rujukan payah, bisa jadi masyarakat terlambat mengenali, jadi terlambat merujuk, bisa jadi T2 yang lama, ada beberapa pasien meninggal diatas 24 jam bahkan beberapa hari, itu artinya ada yang harus dikirim ke tersier, pasiennya ga mau."(RN1, Indepth)

\section{3) Peran Faktor Penyebab Kematian} Maternal yang Dapat Dicegah Terhadap Keterlambatan Rujukan dan Penanganan Tabel 5. Distribusi Frekuensi Peran Faktor Pasien Terhadap Keterlambatan Rujukan dan Penanganan di Kabupaten Karawang Tahun $2015(\mathrm{n}=65)$

\begin{tabular}{|c|c|c|c|c|c|c|c|c|}
\hline \multirow{3}{*}{ No } & \multirow{3}{*}{ Variabel } & \multicolumn{4}{|c|}{$\begin{array}{c}\text { Keterlambatan rujukan } \\
\text { dan penanganan }\end{array}$} & \multirow{2}{*}{\multicolumn{2}{|c|}{ Total }} & \multirow{3}{*}{ Nilai $p^{*}$} \\
\hline & & \multicolumn{2}{|c|}{ Terlambat } & \multicolumn{2}{|c|}{$\begin{array}{c}\text { Tidak } \\
\text { terlambat }\end{array}$} & & & \\
\hline & & $\mathrm{n}=52$ & $\%$ & $n=13$ & $\%$ & $\mathbf{n}$ & $\%$ & \\
\hline 1 & $\begin{array}{l}\text { Umur } \\
\text { Berisiko } \\
\text { Tidak beresiko }\end{array}$ & $\begin{array}{l}10 \\
42\end{array}$ & $\begin{array}{l}66,7 \\
84,0\end{array}$ & $\begin{array}{l}5 \\
8\end{array}$ & $\begin{array}{l}33,3 \\
16,0\end{array}$ & $\begin{array}{l}15 \\
50\end{array}$ & $\begin{array}{l}23,1 \\
76,9\end{array}$ & 0,136 \\
\hline 2 & $\begin{array}{l}\text { Paritas } \\
\text { Berisiko } \\
\text { Tidak Berisiko }\end{array}$ & $\begin{array}{l}16 \\
36\end{array}$ & $\begin{array}{l}69,6 \\
85,7\end{array}$ & $\begin{array}{l}7 \\
6\end{array}$ & $\begin{array}{l}30,4 \\
14,3\end{array}$ & $\begin{array}{l}23 \\
42\end{array}$ & $\begin{array}{l}35,4 \\
64,6\end{array}$ & 0,110 \\
\hline 3 & $\begin{array}{l}\text { Jarak Kelahiran } \\
\text { Berisiko } \\
\text { Tidak berisiko }\end{array}$ & $\begin{array}{c}2 \\
42\end{array}$ & $\begin{array}{l}40,0 \\
85,7\end{array}$ & $\begin{array}{l}3 \\
7\end{array}$ & $\begin{array}{l}60,0 \\
14,3\end{array}$ & $\begin{array}{c}5 \\
49\end{array}$ & $\begin{array}{l}7,7 \\
75,4\end{array}$ & 0,039 \\
\hline 4 & $\begin{array}{l}\text { Pendidikan } \\
\text { Dasar } \\
\text { Menengah }\end{array}$ & $\begin{array}{c}48 \\
4\end{array}$ & $\begin{array}{l}87,3 \\
40,0\end{array}$ & $\begin{array}{l}7 \\
6\end{array}$ & $\begin{array}{l}12,7 \\
60,0\end{array}$ & $\begin{array}{l}55 \\
10\end{array}$ & $\begin{array}{l}84,6 \\
15,4\end{array}$ & 0,003 \\
\hline 5 & $\begin{array}{l}\text { Penyakit Penyerta } \\
\text { Ada penyakit } \\
\text { Tanpa penyakit }\end{array}$ & $\begin{array}{l}21 \\
31\end{array}$ & $\begin{array}{l}72,4 \\
86,1\end{array}$ & $\begin{array}{l}8 \\
5\end{array}$ & $\begin{array}{l}27,6 \\
13,9\end{array}$ & $\begin{array}{l}29 \\
36\end{array}$ & $\begin{array}{l}44,6 \\
55,4\end{array}$ & 0,145 \\
\hline 6 & $\begin{array}{l}\text { Kunjungan ANC } \\
<4 \mathrm{Kali} \\
\geq 4 \mathrm{Kali}\end{array}$ & $\begin{array}{l}14 \\
38\end{array}$ & $\begin{array}{l}77,8 \\
80,9\end{array}$ & $\begin{array}{l}4 \\
9\end{array}$ & $\begin{array}{l}22,2 \\
19,1\end{array}$ & $\begin{array}{l}18 \\
47\end{array}$ & $\begin{array}{l}27,7 \\
72,3\end{array}$ & 0,515 \\
\hline
\end{tabular}

Tabel 5 menunjukkan sebagian besar kematian maternal yang dapat dicegah terdapat pada ibu dengan kategori umur tidak berisiko atau usia reproduktif (20-35 tahun) yaitu sebanyak 50 kasus (76,9\%). Kategori umur tidak berisiko yang mengalami keterlambatan sebanyak 42 kasus $(84,0 \%)$ dengan nilai $p=$ $0,136(>0,05)$ artinya tidak terdapat peran umur yang bermakna terhadap keterlambatan rujukan dan penanganan. Seperti penuturan partisipan berikut:

"4 terlalu masih merupakan penyebab di kami, di usia reproduksi sehat 20-35 tahun merupakan usia yang paling aman untuk hamil tapi banyak menyumbang kematian karena banyak yang hamil pada usia itu, bukan artinya usia tersebut berisiko, ada juga gini..istri baru, suami baru tapi usianya sudah tua, suaminya nuntut punya anak..padahal dah sama-sama punya anak." (RN1 Indepth)

Berdasarkan paritas menunjukkan sebagian besar kematian maternal yang dapat dicegah berada pada kategori tidak berisiko (paritas 2-4) yaitu sebanyak 42 kasus $(64,6 \%)$. Kategori paritas tidak berisiko yang mengalami keterlambatan sebanyak 36 kasus $(85,7 \%)$ dengan nilai $p=0,110(>0,05)$ artinya tidak terdapat peran paritas yang bermakna terhadap keterlambatan rujukan dan penanganan. Seperti penuturan partisipan berikut:

"Bahkan ada yang G12 masih ingin punya anak lagi, ada yang G8, ada juga paritas tidak berisiko tapi usia udah 41 tahun, masih belum mau ber KB, kadang istrinya mau ber KB tapi suami ga setuju."(RNI Indepth)

Berdasarkan jarak kelahiran menunjukkan sebagian besar kematian maternal yang dapat dicegah berada pada kategori tidak berisiko (> 2 tahun) sebanyak 49 kasus $(75,4 \%)$. Terdapat 11 kasus $(16,2 \%)$ dengan kehamilan pertama. Kategori jarak kehamilan tidak berisiko yang mengalami keterlambatan sebanyak 42 kasus $(85,7 \%)$ dengan nilai $p=$ $0,039(<0,05)$ artinya terdapat peran jarak kelahiran yang bermakna terhadap keterlambatan rujukan dan penanganan. Seperti penuturan partisipan berikut:

"Jarak kelahiran itu terlalu jauh atau dekat karena unmeet need $K B$, atau merasa ga bisa 
hamil lagi..jadi ga ber-KB makanya hamil atau dari suami kedua."(R2 FGD 2)

"Berarti itu perencanaan family planingnya, ada yang kerja lupa KB sudah punya anak, pengetahuan di masyarakat harus di tingkatkan bagaimana perencanaan KB, kalau aman 20-35 tahun, jarak aman 5 tahun, jangan sampai terlalu jauh umur hamil lagi, udah terlalu tua, itu yang kadang masyarakat tidak tahu..harusnya tenaga kesehatan memberikan edukasi bagaimana merencanakan kehamilan"(RNI Indepth)

Berdasarkan pendidikan menunjukkan sebagian besar kematian maternal yang dapat dicegah berada pada kategori pendidikan dasar sebanyak 55 kasus $(84,6 \%)$ dan kategori pendidikan dasar yang mengalami keterlambatan sebanyak 48 kasus $(87,3 \%)$ dengan nilai $p=0,003(<0,05)$ artinya terdapat peran pendidikan yang bermakna terhadap keterlambatan rujukan dan penanganan. Seperti penuturan partisipan berikut:

"Tingkat pendidikan masyarakatnya kan masih rendah, jadi tingkat pemahaman masyarakatnya rendah, pemahaman mereka kan beda-beda ya..sampai mereka merasakan sekali, baru ngerti mereka."(R1 FGD 2)

"Kalau yang jadi masalah masih banyak pendidikan rata-rata $S D$ karena dinikahkan pada usia muda, jadinya susah dari segi pengetahuan, sehingga tidak punya kemampuan untuk mengambil keputusan secara pribadi." (RI FGD 1)

Berdasarkan penyakit penyerta menunjukkan sebagian besar kematian maternal yang dapat dicegah berada pada kategori tanpa penyakit penyerta sebanyak 36 kasus $(55,4 \%)$. Kategori tanpa penyakit penyerta yang mengalami keterlambatan sebanyak 31 kasus $(86,1 \%)$ dengan nilai $p=0,145(>0,05)$ artinya tidak terdapat peran penyakit penyerta yang bermakna terhadap keterlambatan rujukan dan penanganan. Seperti penuturan partisipan berikut:

"Ada kematian karena sakit jantung, sudah ditangani ahli jantung, umur 4 bulan mau digugurin ama dokter, suami mau, tapi istri ga mau, cuma punya anak satu, gimana nasib ajalah, gitu katanya." (RN6 Indepth)
"Lebih cenderung ibu sendiri yang kurang ANC sehingga banyak kasus tidak terdeteksi, kita banyak kasus yang hamilnya karena tidak diinginkan ditutup-tutupi sehingga ga datang periksa kehamilan, hampir seтиa kematian tahun kemarin seperti itu, padahal sudah berbagai upaya kita lakukan." (R2 FGD 1)

Berdasarkan kunjungan ANC menunjukkan sebagian besar kematian maternal yang dapat dicegah berada pada kategori $\geq 4$ kali kunjungan sebanyak 47 kasus $(72,3 \%)$. Kategori kunjungan ANC $\geq 4$ kali yang mengalami keterlambatan sebanyak 38 kasus $(80,9 \%)$ dengan nilai $p=0,515(>0,05)$ artinya tidak terdapat peran kunjungan ANC yang bermakna terhadap keterlambatan rujukan dan penanganan. Seperti penuturan partisipan berikut:

"Itu yang patut dipertanyakan..kami sudah memberikan kebijakan, pembinaan terkait ANC terpadu dan berkualitas harus $10 \mathrm{~T}$, tapi tetap juga dilapangan $\mathrm{Hb}$ ga diperiksa, segala upaya sudah dilakukan, di bina ANC, deteksi, skrining ibu hamil, untuk kasus gawat darurat bagaimana cara stabilisasi, masih aja beberapa daerah tidak bisa."(RN1 Indepth)

Tabel 6 Distribusi Frekuensi dan Peran Faktor Tenaga Kesehatan Terhadap Keterlambatan Rujukan dan Penanganan di Kabupaten Karawang Tahun $2015(\mathrm{n}=65)$

\begin{tabular}{|c|c|c|c|c|c|c|c|c|}
\hline \multirow{3}{*}{ No } & \multirow{3}{*}{ Variabel } & \multicolumn{4}{|c|}{$\begin{array}{c}\text { Keterlambatan rujukan } \\
\text { dan Penanganan }\end{array}$} & \multirow{2}{*}{\multicolumn{2}{|c|}{ Total }} & \multirow{3}{*}{ Nilai $p^{*}$} \\
\hline & & \multicolumn{2}{|c|}{ Terlambat } & \multicolumn{2}{|c|}{$\begin{array}{c}\text { Tidak } \\
\text { terlambat }\end{array}$} & & & \\
\hline & & $n=52$ & $\%$ & $n=13$ & $\%$ & n & $\%$ & \\
\hline 1 & $\begin{array}{l}\text { Penolong persalinan } \\
\text { Non tenaga kesehatan } \\
\text { Tenaga kesehatan } \\
\text { Hamil }\end{array}$ & $\begin{array}{c}3 \\
39\end{array}$ & $\begin{array}{l}100 \\
83,0\end{array}$ & $\begin{array}{l}0 \\
8\end{array}$ & $\begin{array}{c}0 \\
17,0\end{array}$ & $\begin{array}{c}3 \\
47 \\
15\end{array}$ & $\begin{array}{l}4,6 \\
72,3 \\
23,1\end{array}$ & 0,586 \\
\hline 2 & $\begin{array}{l}\text { Ketersediaan tenaga } \\
\text { kesehatan } \\
\text { Tidak mencukupi } \\
\text { Mencukupi }\end{array}$ & $\begin{array}{c}8 \\
44\end{array}$ & $\begin{array}{l}100 \\
77,2\end{array}$ & $\begin{array}{c}0 \\
13\end{array}$ & $\begin{array}{c}0 \\
22,8\end{array}$ & $\begin{array}{c}8 \\
57\end{array}$ & $\begin{array}{l}12,3 \\
87,7\end{array}$ & 0,149 \\
\hline 3 & $\begin{array}{l}\text { Ketersediaan } \\
\text { pelayanan kesehatan } \\
\text { Tidak mencukupi } \\
\text { Mencukupi }\end{array}$ & $\begin{array}{l}41 \\
11\end{array}$ & $\begin{array}{l}97,6 \\
47,8\end{array}$ & $\begin{array}{c}1 \\
12\end{array}$ & $\begin{array}{l}2,4 \\
52,2\end{array}$ & $\begin{array}{l}42 \\
23\end{array}$ & $\begin{array}{l}64,6 \\
35,4\end{array}$ & 0,000 \\
\hline
\end{tabular}


Tabel 6 menunjukkan sebagian besar kematian maternal yang dapat dicegah dengan penolong persalinan oleh tenaga kesehatan yaitu sebanyak 47 kasus $(72,3 \%)$. Terdapat 15 kasus $(23,1 \%)$ kematian terjadi pada masa hamil. Kategori penolong persalinan oleh tenaga kesehatan yang mengalami keterlambatan sebanyak 39 kasus $(83,0 \%)$ dengan nilai $p=0,586(>0,05)$ artinya tidak terdapat peran penolong persalinan yang bermakna terhadap keterlambatan rujukan dan penanganan. Seperti penuturan partisipan berikut:

"Nolong partus udah 4 tangan jadi 2 orang, misalnya ada partus di rumah, pasti saya panggil bidan lain untuk bantu, kalau pasien manggil paraji ya parajinya antar kekita, paraji ga nolong lagi." (RN3 Indepth)

"Kita ada kemitraan dengan paraji, saat paraji nolong panggil bidan, saat bidan nolong menelpon paraji karena paraji yang ngurus perawatan selanjutnya." (R2 FGD 1)

Berdasarkan ketersediaan tenaga kesehatan menunjukkan sebagian besar kematian maternal yang dapat dicegah dengan ketersediaan tenaga kesehatan mencukupi sebanyak 57 kasus $(87,7 \%)$. Kategori ketersediaan tenaga kesehatan mencukupi yang mengalami keterlambatan sebanyak 44 kasus $(77,2 \%)$ dengan nilai $p=0,149(>0,05)$ artinya tidak terdapat peran ketersediaan tenaga kesehatan yang bermakna terhadap keterlambatan rujukan dan penanganan. Seperti penuturan partisipan berikut:

"Kita ngerujuk sendiri karena jelas bidan desa ga tanggung jawab, pasien apapun ga pernah di antar, permasalahan di kita bidan yang bermasalah, bidan ga ada konfirmasi bahkan ada kasus..kita ditanya punya uang berapa, terus diarahin ke swasta, katanya jamkesmas tidak berlaku."(RK5 Indepth)

Berdasarkan ketersediaan pelayanan kesehatan menunjukkan sebagian besar kematian maternal yang dapat dicegah dengan ketersediaan pelayanan kesehatan tidak mencukupi sebanyak 42 kasus (61,8\%). Kategori ketersediaan pelayanan kesehatan tidak mencukupi yang mengalami keterlambatan sebanyak 41 kasus $(97,6 \%)$ dengan nilai $p=0,000(<0,05)$ artinya terdapat peran ketersediaan pelayanan kesehatan yang bermakna terhadap keterlambatan rujukan dan penanganan. Seperti penuturan partisipan berikut:

"Kemampuan standar untuk pelayanan tidak sama, untuk kerjasama lintas sektor memang ada kendala terutama pembinaan klinik, BPS itu memang tugas puskesmas, dan itu merupakan kelemahan di kita.(RI FGD 2)

"Kelemahan di kita misalada kematian ibu di A, KTP di B terus periksa atau ditolong di $C$, kadang bidan A ga tau, yang memberikan pelayanan bidan lain." (R2 FGD 2)

Tabel 7 Distribusi Frekuensi dan Peran Faktor Fasilitas Kesehatan Terhadap Keterlambatan Rujukan dan Penanganan di Kabupaten Karawang Tahun $2015(\mathrm{n}=65)$

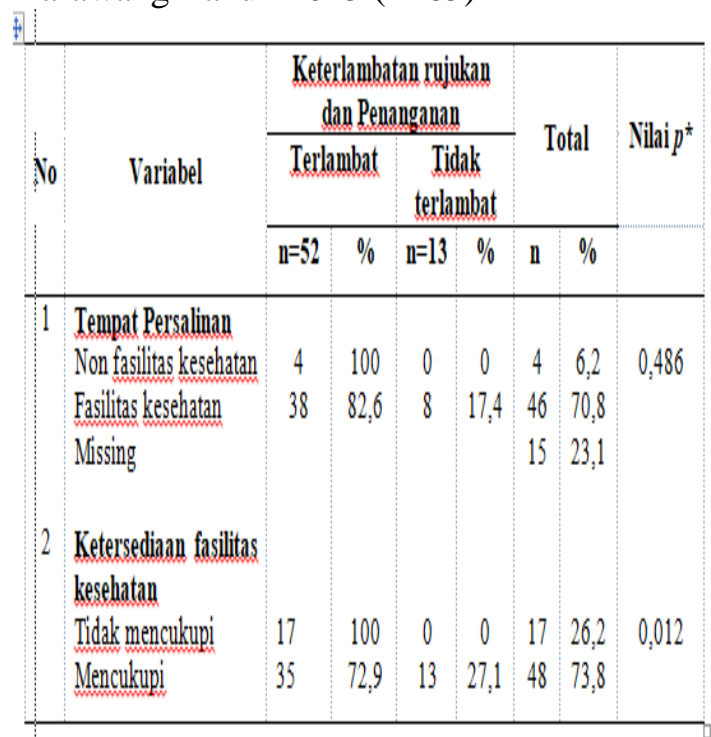

Tabel 7 menunjukkan sebagian besar kematian maternal yang dapat dicegah dengan tempat persalinan di fasilitas kesehatan sebanyak 46 kasus $(70,8 \%)$. Terdapat 15 kasus $(23,1 \%)$ kematian pada masa hamil. Kategori tempat persalinan di fasilitas kesehatan yang mengalami keterlambatan sebanyak 38 kasus $(82,6 \%)$ dengan nilai $p=0,486(>0,05)$ artinya tidak terdapat peran tempat persalinan yang bermakna terhadap keterlambatan rujukan dan penanganan. Seperti penuturan partisipan berikut:

"Masih ada yang menolong persalinan di rumah pasien, kalau dipanggil biasa karena 
brojol..ya kita motivasi biar melahirkan di fasilitas kesehatan."(RN3 Indepth)

"Lama di keluarga untuk mengambil keputusan, malah disini orang tua pihak perempuan masih dominan, kendala ada penyakit kalau belum parah belum dirujuk maunya melahirkan dirumah terkait ekonomi." (R3 FGD 1)

Berdasarkan ketersediaan fasilitas kesehatan menunjukkan sebagian besar kematian maternal yang dapat dicegah dengan ketersediaan fasilitas kesehatan mencukupi sebanyak 48 kasus $(73,8 \%)$. Kategori ketersediaan fasilitas kesehatan mencukupi yang mengalami keterlambatan sebanyak 35 kasus $(72,9 \%)$ dengan nilai $p=0,012(<0,05)$ artinya terdapat peran ketersediaan fasilitas kesehatan yang bermakna terhadap keterlambatan rujukan dan penanganan. Seperti penuturan partisipan berikut:

"Yang ada di klinik dokter umum dengan perawat, ga diperiksa disuruh cari oksigen ke bidan $H$, bidan $H$ ga ada pergi ke bidan I, jadi naik becak ke bidan I karena udah kejangkejang jadi meninggal dijalan. "(RK6 Indepth)

"Di semua rumah sakit sudah ditanya ICU penuh, ke rumah sakit $S 1$ jam setengah, ambulan ga ada peralatan lengkap alat medis, jadi tunggu ambulan 4 jam datang dari jakarta, udah sampai kesana udah terlambat, kalau perjalanan cepat."(RKI Indepth)

Tabel 8 Distribusi Frekuensi dan Peran Faktor Rujukan Terhadap Keterlambatan Rujukan dan Penanganan di Kabupaten Karawang Tahun $2015(n=65)$

\begin{tabular}{|c|c|c|c|c|c|c|c|c|}
\hline \multirow{3}{*}{ No } & \multirow{3}{*}{ Variabel } & \multirow{2}{*}{\multicolumn{4}{|c|}{$\begin{array}{l}\text { Keterlambantan rujulcan dom } \\
\text { penauganan }\end{array}$}} & \multirow{2}{*}{\multicolumn{2}{|c|}{ Total }} & \multirow{3}{*}{ Nilni $p^{*}$} \\
\hline & & & & & & & & \\
\hline & & $n=52$ & $\%$ & \multicolumn{2}{|c|}{$\begin{array}{l}\text { Touale } \\
\text { terlaumbat } \\
n=13\end{array}$} & $\mathbf{n}$ & $\%$ & \\
\hline 1 & 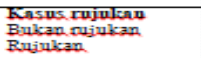 & $\begin{array}{l}6 \\
46\end{array}$ & $\begin{array}{l}85.7 \\
79.3\end{array}$ & $\begin{array}{l}1 \\
12\end{array}$ & $\begin{array}{l}14.3 \\
20.7\end{array}$ & $\begin{array}{l}7 \\
58\end{array}$ & $\begin{array}{l}10.8 \\
89.2\end{array}$ & 0.572 \\
\hline 2 & $\begin{array}{l}\text { Wilaysh temanat } \\
\text { tingegal } \\
\text { perdesam } \\
\text { Perkotasan }\end{array}$ & $\begin{array}{l}23 \\
29\end{array}$ & $\begin{array}{l}82.1 \\
78.4\end{array}$ & $\begin{array}{l}5 \\
8\end{array}$ & $\frac{17.9}{21.6}$ & $\begin{array}{l}28 \\
37\end{array}$ & $\begin{array}{l}43.1 \\
56.9\end{array}$ & 0.479 \\
\hline 3 & $\begin{array}{l}\text { Geografis tempat } \\
\text { tiugegal } \\
\text { Dataran Tingei } \\
\text { Dataran Rendah }\end{array}$ & $\stackrel{2}{50}$ & $\begin{array}{l}100 \\
79.4\end{array}$ & $\begin{array}{l}0 \\
13\end{array}$ & 20.6 & 2 & $\begin{array}{l}3.1 \\
96.9\end{array}$ & 0.638 \\
\hline 4 & $\begin{array}{l}\text { Jaralk Tempuh } \\
75 \mathrm{~km} \\
\leq 5 \mathrm{kcm}\end{array}$ & $\frac{45}{7}$ & $\begin{array}{l}78.9 \\
87.5\end{array}$ & $\begin{array}{c}12 \\
1\end{array}$ & $\begin{array}{ll}21.1 \\
12.5\end{array}$ & $\begin{array}{l}57 \\
8\end{array}$ & $\begin{array}{l}87.7 \\
12.3\end{array}$ & 0.494 \\
\hline 5 & $\begin{array}{l}\text { Waltu Tempuh } \\
\text { >2 } \mathrm{jam} \\
\leq 2 \mathrm{jam}\end{array}$ & $\begin{array}{l}3 \\
49\end{array}$ & $\begin{array}{l}100 \\
79.0\end{array}$ & $\stackrel{0}{13}$ & 21.0 & $\begin{array}{l}3 \\
62\end{array}$ & $9,6.4$ & 0.506 \\
\hline 6 & $\begin{array}{l}\text { Alnt Transportani } \\
\text { Tidak tersedia } \\
\text { Tersedia }\end{array}$ & $\begin{array}{l}3 \\
49\end{array}$ & $\begin{array}{l}100 \\
79.0\end{array}$ & $\begin{array}{l}0 \\
13\end{array}$ & 21.0 & $\begin{array}{l}3 \\
62\end{array}$ & 95.6 & 0.506 \\
\hline 7 & 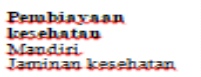 & $\begin{array}{l}24 \\
28\end{array}$ & $\begin{array}{l}80.0 \\
80.0\end{array}$ & $\stackrel{6}{7}$ & $\begin{array}{l}20.0 \\
20.0\end{array}$ & $\begin{array}{l}30 \\
35\end{array}$ & 56.2 & 0.620 \\
\hline 8 & $\begin{array}{l}\text { Administrasi } \\
\text { Mdengalami kesulitan } \\
\text { Tidali mengalami } \\
\text { kcesulitan }\end{array}$ & $\begin{array}{l}11 \\
41\end{array}$ & $\begin{array}{l}100 \\
75.9\end{array}$ & $\begin{array}{l}0 \\
13\end{array}$ & $\begin{array}{c}0 \\
24.1\end{array}$ & $\begin{array}{l}11 \\
54\end{array}$ & $\begin{array}{l}16.9 \\
83.1\end{array}$ & 0.607 \\
\hline
\end{tabular}

Tabel 8 menunjukkan sebagian besar kematian maternal yang dapat dicegah dengan kasus rujukan sebanyak 58 kasus (89,2\%). Kategori kasus rujukan yang mengalami keterlambatan sebanyak 46 kasus $(79,3 \%)$ dengan nilai $p=0,572(>0,05)$ artinya tidak terdapat peran kasus rujukan yang bermakna terhadap keterlambatan rujukan dan penanganan. Seperti penuturan partisipan berikut:

"Ga mau dirujuk, pengambil keputusan yang berperan keluarga, kita ga bisa intervensi, udah mau meninggal baru dirujuk, disini rata rata keluarga yang susah, mobil sudah disediain, biaya ada, siapa nanggung sekeluarga yang datang." (RI FGD 1)

"Yang jadi masalah, tidak semua rumah sakit terlatih PONEK jadi selama ini kalau merujuk paling ke tiga rumah sakit yang sudah PONEK, kalau rujuk ke RS terdekat ujungujung dirujuk lagi." (RI FGD 2)

Berdasarkan wilayah tempat tinggal menunjukkan sebagian besar kematian maternal yang dapat dicegah berada di wilayah perkotaan sebanyak 37 kasus (56,9\%). Kategori wilayah tempat tinggal perkotaan yang mengalami keterlambatan sebanyak 29 kasus $(78,4 \%)$ dengan nilai $p=0,479(>0,05)$ artinya tidak terdapat peran wilayah tempat tinggal yang bermakna terhadap keterlambatan rujukan dan penanganan. Seperti penuturan partisipan berikut:

"Sebenarnya sudah tidak ada kendala berkaitan dengan tempat tinggal apalagi pasien yang dirujuk sudah ada sms gathway, dari call center pun sudah menunjuk rumah sakit yang siap, jadi tidak ada yang namanya kendala dioper kesana kemari."(RI FGD 2)

"Untuk rujukan ga ada kendala meski jauh di penghujung, ambulan standby, mobil operasional desa juga selalu ada..kalau ada masayarakat bandel, ga mau dirujuk, kita panggil aja kepala desanya, jadi pak kades ikut turun, kalau ga ada mobil di desa, kita pinjam mobil desa tetangga. "(RN6 Indepth)

Berdasarkan geografis tempat tinggal menunjukkan hampir semua kematian maternal yang dapat dicegah berada di dataran rendah sebanyak 63 kasus $(96,9 \%)$. Kategori geografis tempat tinggal dataran rendah yang mengalami 
keterlambatan sebanyak 50 kasus $(79,4 \%)$ dengan nilai $\mathrm{p}=0,638(>0,05)$ artinya tidak terdapat peran geografis tempat tinggal yang bermakna terhadap keterlambatan rujukan dan penanganan. Seperti penuturan partisipan berikut:

"Kalau yg arah kesana..paling nyebrang ke arah cikarang atau daerah bekasi, sebetulnya boleh aja merujuk lintas batas tergantung keinginan pasien."(RN6 Indepth)

Berdasarkan jarak tempuh menunjukkan sebagian besar kematian maternal yang dapat dicegah dengan jarak tempuh > 5 km sebanyak 57 kasus $(87,7 \%)$. Kategori jarak tempuh $>5 \mathrm{~km}$ yang mengalami keterlambatan sebanyak 45 kasus $(78,9 \%)$ dengan nilai $p=$ $0,494(>0,05)$ artinya tidak terdapat peran jarak tempuh yang bermakna terhadap keterlambatan rujukan dan penanganan. Seperti penuturan partisipan berikut:

"Kalau untuk jarak tempuh ada dua yang jauh, harus melewati sungai yaitu ciampel dan cibuaya, tapi cibuaya sudah ada jembatan, dulu pakai perahu."(RN1 Indepth)

"Mobil ambulan ada dua di puskesmas, walaupun jauh ga masalah karena mobil ambulannya ada lampu jadi cepat dan jalan sudah bagus." (RI FGD 1)

Berdasarkan waktu tempuh menunjukkan sebagian besar kematian maternal yang dapat dicegah dengan waktu tempuh $\leq 2$ jam sebanyak 62 kasus (95,4\%). Kategori waktu tempuh $\leq 2$ jam yang mengalami keterlambatan sebanyak 49 kasus $(79,0 \%)$ dengan nilai $p=0,506(>0,05)$ artinya tidak terdapat peran waktu tempuh yang bermakna terhadap keterlambatan rujukan dan penanganan. Seperti penuturan partisipan berikut:

"Kalau ke RSUD lamanya satu jam setengah, kalau ambulans bisa motong jalan, lebih baik lama dijalan, daripada lama tindakan, anggapan masyarakat disini kejauhan ke RSUD, padahal di RSUD udah lengkap persediaan, kalau di sini dekat aja jarak apapun ga ada. "(RN5 Indepth)

Berdasarkan alat transportasi menunjukkan sebagian besar kematian maternal yang dapat dicegah dengan tersedia alat transportasi sebanyak 62 kasus $(95,4 \%)$.
Kategori alat transportasi tersedia yang mengalami keterlambatan sebanyak 49 kasus $(79,0 \%)$ dengan nilai $p=0,506(>0,05)$ artinya tidak terdapat peran alat transportasi yang bermakna terhadap keterlambatan rujukan dan penanganan. Seperti penuturan partisipan berikut:

"Punya 50 pusling, dan tahun ini kita mengadakan 29 ambulan khusus penyelamatan ibu dan bayi, kalau di desa ada kendaraan operasional desa bukan ambulan tapi bisa dipakai untuk merujuk pasien, tahun 2016 ini dapat ambulan dana $A B N$ untuk penyelamatan ibu dan bayi." (RN1 Indepth)

"Merujuk kadang ga pake ambulan, ada mobil operasional desa tapi kan tidak standar seperti ambulan, peralatan ga ada, tidak ada oksigen, tapi bisa dipakai mengantar orang sakit, seperti mobil pribadi." (R2 FGD 2)

"Kendalanya meskipun transportasi ada tapi lintas sector kurang mendukun, saya pernah ngerujuk pasien pake mobil kol buntung, gara gara saya telfon aparat desa, saya sms ga dijawab, sedangkan pasien sudah perdarahan, jadi kendala disitu, kurangnnya perhatian aparat desa." (R3 FGD 2)

Berdasarkan pembiayaan kesehatan menunjukkan sebagian besar kematian maternal yang dapat dicegah memiliki jaminan kesehatan sebanyak 35 kasus (53,8\%). Kategori pembiayaan kesehatan dengan jaminan kesehatan yang mengalami keterlambatan sebanyak 28 kasus $(80,0 \%)$ dengan nilai $p=$ $0,620(>0,05)$ artinya tidak terdapat peran pembiayaan kesehatan yang bermakna terhadap keterlambatan rujukan dan penanganan. Seperti penuturan partisipan berikut:

"Jaminan itu bentuknya bisa jaminan finansial ada dengan kartu jaminan, semuanya di arahkan untuk memiliki kartu jaminan. Kita sudah upayakan semua yang kontak dengan bidan, harus ditanya sudah punya kartu jaminan atau tidak." (R2 FGD 2)

"Kendalanya masyarakat masih menganggap persalinan di tenaga kesehatan mahal, padahal udah sosialisasi, udah dianjurkan bikin BPJS dari hamil 6 bulan, calon bayi juga, tapi susah banget, gimana nanti aja katanya, boro-boro calon bayi, buat ibu aja susah. KIS aja ga semua dapat, ga tau pendataan gimana, ga 
seтиa masyarakat ga mampu dapat KIS. "'(RN3 Indepth)

"Udah ada biaya dari pemerintah, kadang kita mikir, siapa yang nunggunya di rumah sakit, di mana dapat biaya buat makan dan sebagainya. "(RK5 Indepth)

Berdasarkan administrasi menunjukkan sebagian besar kematian maternal yang dapat dicegah tidak mengalami kesulitan administrasi sebanyak 54 kasus $(83,1 \%)$. Kategori tidak mengalami kesulitan administrasi yang mengalami keterlambatan sebanyak 41 kasus $(75,9 \%)$ dengan nilai $p=0,607(>0,05)$ artinya tidak terdapat peran administrasi yang bermakna terhadap keterlambatan rujukan dan penanganan. Seperti penuturan partisipan berikut:

"Masalah administrasi tidak jadi masalah karena nanti langsung kita minta bantuan TKSK yang ada di kecamatan soal ngurusin jaminan kesehatan." (R1 FGD 1)

"Kendalanya yang dari luar Karawang yang bukan penduduk asli, tidak punya BPJS, mau dirujuk kendala dengan syarat, kadang rumah sakit swasta salah memberikan informasi, pasien disuruh mencari rujukan ke puskesmas sehingga lambat penanganan, padahal kasus gawat darurat tidak memerlukan rujukan puskesmas." (R2 FGD 2)

"Kartu KIS pendataan tidak bisa langsung. Kita data ribuan, yang keluar ratusan. Kadang masyarakat banyak belum punya KTP, KK, waktu perekaman KTP elektrik tidak ada. Surat pindah ga mampu buat, untuk makan aja susah, banyak kesulitan identitas terkait biaya operasional meski negara sudah membabaskan, untuk berangkat ngurus butuh biaya. Kita berusaha selamatkan pasien urusan administrasi belakangan." (RP4 Indepth)

\section{PEMBAHASAN}

\section{1) Kematian Maternal}

Berdasarkan telaah dokumen OVM/RMM/RMMP didapatkan sebagian besar kematian maternal yang terjadi di Kabupaten Karawang bisa dicegah. Hal ini sesuai dengan penelitian yang menyatakan bahwa sebagian besar kematian maternal di negara-negara berkembang dapat dicegah yaitu 37-90\% (Liang dkk, 2011).

\section{2) Faktor Penyebab Kematian Maternal Yang Dapat Dicegah}

Penyebab kematian maternal yang dapat dicegah dari faktor pasien di Kabupaten Karawang yaitu menikah dini dan tidak melanjutkan pendidikan yang berdampak kurangnya pengetahuan dan pemahaman tentang bahaya dan risiko kehamilan sehingga tidak bisa menentukan keputusan terbaik untuk kesehatan reproduksinya.

Hasil penelitian di Kenya menunjukkan bahwa pendidikan ibu merupakan faktor risiko penting pada kematian maternal. Pendidikan memungkinkan akses terhadap informasi dan membantu memberdayakan perempuan dan pasangan untuk membuat keputusan yang tepat selama kehamilan (Yego, dkk, 2014). Ibu berpendidikan tinggi akan lebih luas tingkat pengetahuan karena lebih besar peluang terpapar dengan informasi terkait kesehatan dan risiko kehamilan. Ibu yang berpendidikan rendah (SD ke bawah) berpeluang 1,4 kali mengalami risiko kehamilan (Puti, dkk, 2014).

Di Kabupaten Karawang masih terdapat ibu yang sibuk bekerja sehingga tidak menggunakan kontrasepsi yang menyebabkan hamil di usia tua atau dengan jarak kelahiran terlalu dekat atau jauh.

Paritas berisiko adalah $\leq 1$ atau $>4$, paritas $\leq 1$ dan usia muda berisiko karena ibu belum siap secara medis/mental, sedangkan paritas $>4$ dan usia tua secara fisik mengalami kemunduran fungsi reproduksi, namun kehamilan kedua atau ketiga jika terjadi saat tidak diharapkan atau interval terlalu pendek dapat meningkatkan risiko kematian maternal (Aeni, 2013).

Terdapat juga ibu yang hamil di usia tua dengan pasangan baru sehingga menutupi kehamilan karena malu dan tidak melakukan pemeriksaan kehamilan berdampak tidak terdeteksi penyulit yang menyertai kehamilan sehingga terlambat mendapatkan penanganan.

Hasil penelitian di Kenya menunjukkan perempuan dengan kehamilan yang diinginkan lebih mungkin melakukan pemerikasaan antenatal sementara dengan kehamilan yang tidak diinginkan kurang melakukan pemeriksaan antenatal, tetapi lebih cenderung untuk pemeriksaan antenatal pada akhir 
kehamilan atau kurang dari empat kali kunjungan (Ochako \& Gichuhi, 2016). Pelayanan antenatal merupakan faktor risiko penting pada kematian maternal. Kunjungan antenatal dapat memberikan kesempatan untuk mendeteksi faktor risiko, dan penyakit yang mendasari tapi kunjungan harus sering dan tepat waktu (Yego, dkk, 2014).

Hasil penelitian di Ethiopia menyebutkan penyakit yang diderita ibu selama kehamilan mempunyai hubungan yang signifikan terhadap peningkatan langsung kematian maternal (Godevay, dkk, 2015). Kematian maternal akibat penyakit yang diderita sebelum kehamilan pada dasarnya dapat dicegah dengan deteksi sejak dini (Aeni, 2013).

Penyebab dari faktor tenaga kesehatan yang berkaitan dengan kematian maternal di Kabupaten Karawang yaitu pemanfaatan paraji sebagai penolong persalinan dan penolong pertama pada saat terjadi kegawatdaruratan, menghubungi tenaga kesehatan pada kondisi yang sudah parah serta masih ada kasus yang tidak tersedianya tenaga profesional.

Penelitian di Cilacap menunjukkan bahwa terdapat beberapa kasus kematian maternal berkaitan dengan ketidakmampuan/kesalahan petugas kesehatan dalam memberikan pertolongan medis, masih terdapat pertolongan persalinan oleh paraji tanpa pendampingan oleh bidan yang memperlambat pelaksanaan rujukan bagi ibu yang mengalami komplikasi (Fibriana \& Azam, 2010). Masih terdapat pemanfaatan paraji dalam melakukan pertolongan persalinan menjadi salah satu faktor penting yang berkontribusi pada meningkatknya risiko kematian maternal (Mundayat, dkk, 2010).

Penyebab dari faktor fasilitas kesehatan yang berkaitan dengan kematian maternal di Kabupaten Karawang yaitu masih terdapat persalinan di rumah pasien karena keluarga tidak mau membawa ibu ke fasilitas kesehatan dengan alasan kendala biaya dan dari segi ketersediaan fasilitas di rumah sakit dimana beberapa pasien harus menunggu jadwal untuk dilakukan operasi akibat tidak tersedia fasilitas sehingga dirujuk ke rumah sakit lain yang menyebabkan terlambat penanganan.
Untuk menurunkan angka kematian ibu maka jumlah perempuan yang melahirkan di rumah harus diturunkan secara maksimal. Untuk menurunkan angka melahirkan di rumah, harus tersedia berbagai fasilitas untuk melahirkan yang memadai dan ditangani oleh tenaga kesehatan yang berkualitas (Mundayat, dkk, 2010).

Penyebab dari faktor rujukan yang berkaitan dengan kematian maternal di Kabupaten Karawang yaitu kebanyakan adalah kasus rujukan, baik rujukan ke puskesmass PONED, rumah sakit, atau dari rumah sakit ke rumah sakit lain. Hal ini terjadi karena banyak kasus yang dirujuk bukan pada saat yang tepat tapi sudah dalam kondisi yang parah yang bisa disebabkan oleh keterlambatan keluarga dalam mengambil keputusan dimana masih adanya tradisi pengambilan keputusan harus menunggu suami/orang tua atau karena keterlambatan tenaga kesehatan dalam melakukan deteksi dini dan merujuk bukan langsung ke fasilitas kesehatan yang tepat.

Faktor yang menyebabkan terjadi rujukan terlambat adalah ketika kondisi pasien sudah pada keadaan yang tidak optimum atau dalam kondisi gawat darurat, waktu tempuh lama dan jarak jauh antara rumah dengan pusat rujukan baik antara pusat rujukan primer maupun pusat rujukan sekunder, serta tidak langsung ditolong di rumah sakit (Mbaruku, dkk, 2009).

\section{3) Keterlambatan Rujukan dan Penanganan \\ a) Keterlambatan Deteksi Dini dan Pengambilan Keputusan}

Keterlambatan deteksi dini dan pengambilan keputusan baik oleh pasie/keluarga maupun oleh tenaga kesehatan sangat menentukan kondisi ibu selanjutnya. Ketidakmampuan ibu mengambil keputusan untuk diri sendiri dan keterlambatan keluarga mengambil keputusan karena membutuhkan waktu untuk bermusyawarah masih banyak terjadi serta ketidakmampuan tenaga kesehatan dalam mengenali tanda bahaya sehingga menyebabkan keterlambatan rujukan dan penanganan.

Terlambat memutuskan mencari pertolongan oleh individu, keluarga, atau 
keduanya berhubungan dengan pengambil keputusan dalam keluarga, status perempuan, karakteristik penyakit, jarak dari fasilitas kesehatan, keuangan dan kemungkinan biaya, pengalaman yang lalu dengan sistem pelayanan kesehatan, dan mutu pelayanan yang diterima (Mundayat, dkk, 2010).

\section{b) Keterlambatan Mencapai Fasilitas Kesehatan}

Keputusan untuk merujuk harus dilakukan dengan cepat dan tepat karena proses rujukan melalui proses yang rumit mulai dari memahami keadaan pasien dalam kondisi darurat, melakukan penanganan awal untuk stabilisasi pasien dan menentukan keputusan untuk merujuk ke rumah sakit. Keterlambatan dalam mencapai fasilitas kesehatan karena kesulitan untuk mencari transportasi terutama di daerah pedesaan, keadaan geografis diantaranya jalan yang rusak atau tidak bisa dilalui kendaraan, jarak ke fasilitas kesehatan akan memengaruhi pemanfaatan masyarakat terhadap pelayanan kesehatan.

Meskipun sudah mempunyai jaminan kesehatan namun tidak menjamin keluarga bersedia dirujuk karena terkendala biaya untuk keluarga yang mendampingi saat rujukan serta bagi keluarga yang status ekonomi keatas menolak rujukan ke fasilitas kesehatan pemerintah yang beranggapan pelayanan tidak memuaskan dan lebih merujuk ke lintas batas yang membutuhkan waktu lama, proses pengurusan administrasi bagi penduduk baru atau yang tinggal berpindah tempat, hal ini lah yang menjadi bagian penting yang berperan pada keterlambatan rujukan dan penanganan.

Penelitian di Gambia ditemukan bahwa keterlambatan proses rujukan disebabkan beberapa hal mulai dari keluarga menyadari adanya komplikasi pada ibu, sikap keluarga terhadap kejadian komplikasi yang berkaitan dengan keputusan untuk mencari pertolongan yang tepat, sulitnya transportasi dan perjalanan panjang mencapai fasilitas kesehatan karena harus mencari lebih dari satu fasilitas kesehatan menyebabkan keterlambatan mendapatkan penanganan di rumah sakit rujukan (M Cham \& S Vangen, 2005).

\section{c) Keterlambatan Penanganan di Fasilitas Kesehatan}

Keterlambatan mendapatkan penanganan setelah sampai di fasilitas kesehatan juga disebabkan kurang tersedia tenaga profesional, kurang fasilitas yang memadai, terlambat memutuskan untuk merujuk ke fasilitas kesehatan lain yang lebih lengkap fasilitas maupun tenaga kesehatan sehingga pada akhirnya pasien sudah dalam kondisi parah yang mengakibatkan pelayanan yang diberikan dan upaya penyelamatan tidak efektif.

Penelitian yang dilakukan di Gambia menemukan bahwa kematian maternal terjadi saat terlambat mendapatkan pelayanan di tempat rujukan disebabkan kurang fasilitas obat-obatan, peralatan, staf yang terlatih/staf yang ada kurang kompeten. Kegagalan sistem kesehatan dianggap sebagai faktor yang berperan pada kematian maternal ((M Cham \& $S$ Vangen, 2005).

\section{KESIMPULAN}

Sebagian besar kematian maternal di Kabupaten Karawang yaitu $95,6 \%$ dapat dicegah yang disebabkan keterlambatan keluarga memberikan keputusan, kurangnya deteksi dini oleh keluarga/tenaga kesehatan, kurangnya kualitas ANC dan KIE (komunikasi, informasi dan edukasi), kurangnya kesadaran penggunaan kontrasepsi serta kurang tepat rujukan yang menyebabkan keterlambatan rujukan dan penanganan.

\section{SARAN}

Diperlukan peran serta masyarakat, stakeholder, tenaga kesehatan dan pengambil kebijakan dalam meningkatkan kualitas pelayanan kebidanan untuk menurunkan kematian maternal.

\section{REFERENSI}

Aeni N. (2013). Faktor risiko kematian ibu. Kesmas. Volume Mei;7(10):453-9.

Dinkes Provinsi Jawa Barat. (2014). Profil kesehatan provinsi Jawa Barat.

Dinkes Kabupaten Karawang. (2014). Profil kesehatan kabupaten Karawang. 
Fibriana AI \& Azam M. (2010). Three delay model sebagai salah satu determinan kematian ibu di kabupaten Cilacap. Kesmas. Volume 6(1):16-23.

Godevay H, dkk. (2015). Risk factors for maternal mortality in rural Tigray, Northern Ethiopia: a case-control study. Plos One. Volume Desember 17:1-12.

Kemenkes RI. (2010). Direktorat Jendral Bina Kesehatan Masyarakat. Pedoman Audit Maternal Perinatal.

Kemenkes RI. (2014). Panduan operasional sistem jejaring rujukan kegawatdaruratan ibu dan bayi baru lahir puskesmas - rumah sakit.

Kemenkes RI. (2015). Rencana strategis Kementerian Kesehatan tahun 2015-2019. Jakarta.

Liang J, dkk. (2011). Preventable maternal mortality: Geographic/rural urban differences and associated factors from the population-based maternal mortality surveillance system in China. BMC Public Health. Volume 11(243):1-9.

M Cham JS \& S Vangen. (2005). Maternal mortality in the rural gambia, a qualitative study on acces to emergency obstetric care,. Reproductive Health Journal, Bio Med Central.

Mbaruku G, dkk. (2009). Perinatal audit using the 3-delays model in western Tanzania. International Journal of Gynecology and Obstetrics. Volume 106:85-8.

Mundayat AA, dkk. (2010). Target MDGs menurunkan angka kematian ibu tahun 2015 sulit dicapai.

Merali HS, dkk. (2014). Audit-identified avoidable factors in maternal and perinatal deaths in low resource settings: a systematic review. BMC Pregnancy and Childbirth. Volume 14(280):1-12.

Ochako R, \& Gichuhi W. (2016). Pregnancy wantedness, frequency and timing of antenatal care visit among women of childbearing age in Kenya. Ochako and Gichuhi Reproductive Health, Bio Med Central. Volume 13(51):1-8.
Puti S, Ika D, \& Nunik K. (2014). Faktor-faktor yang berpengaruh terhadap risiko kehamilan 4 terlalu (4 T) pada wanita usia 10-59 tahun (analisis Riskesdas 2010). Media Litbangkes. Volume 24(3):143-52.

WHO. (2014). Global reference list of core health indicators. Working draft version 6 Geneva.

Yego F, dkk. (2014). Risk factors for maternal mortality in a tertiary hospital in Kenya:a case control study. BMC Pregnancy and Childbirth. Volume 14(38):1-9. 